\title{
Methodology for Monitoring the Customer Value Perception of the Service Quality in Small Audit Companies
}

\author{
${ }^{1}$ Kseniya S. Pavlova, ${ }^{2}$ Vladimir I. Barilenko, ${ }^{3}$ Natalia V. Knyazeva, ${ }^{4}$ Tatyana D. Krylova \\ ${ }^{1}$ Samara State University of Economics, Samara, Russia \\ ${ }^{2}$ Financial University under the Government of the Russian Federation, \\ ${ }^{3,4}$ Institute of Commodity Logistic Research and Wholesale Market Situation, Moscow, Russia \\ Email: mrs.pavlova@list.ru,vbarilenko@fa.ru,natali_plus@mail.ru,tdkrilova@gmail.com
}

\section{Received: $2^{\text {th }}$ June 2018, Accepted: $0^{\text {th }}$ August 2018, Published: $31^{\text {st }}$ August 2018}

\begin{abstract}
The urgency of the problem under research is caused by the results of the conducted research on the analysis of the concept of "service values" and existing methods for increasing the customer value perception of audit services, reflecting important aspects of competiveness growth and development of audit business, in particular, small companies. The purpose of the article is to develop methodological provisions for assessing the customer value perception of audit services and improving the perceived service quality. The leading method to study this problem is the development of the methodology for monitoring the customer value perception of audit services, which consists of several stages. Based on the analysis of the customer perception with the help of a number of indicators, a matrix of the value estimation of audit services is formed. The article describes various approaches to the formation of the consumer value perception of services, the authors present a scheme of value factors of demand for audit services, an algorithm for a customer when purchasing audit services, and a classification of services by a qualitative feature compiled by the author. Based on the monitoring of change dynamics in main indicators of the audit market over the past 7 years, the relationship between the impeccable business reputation based on the quality of service delivery and a high value of audit services, as well as the demand of consumers for services of audit companies, have been revealed.
\end{abstract}

Keywords: Audit Services, Value Perception of Services, Value of Services, Value of Audit Services, Perceived Quality, Audit Service Quality

\section{Introduction}

An important problem for the audit market in order to maintain the quality is to ensure a high demand for services, respectively, a stable profitability of the audit organization and, as a consequence, cover variable and fixed costs, create reserves for modernization, increase volumes and range of services. In this aspect, methods for stimulating demand, using competitive strategies and methods for creating the cost and price of services are of particular relevance. In particular, the value approach to the formation of value and demand for audit services is of particular importance.

The customer's preferences of the target audience are due to differences in the value of the audit offer and the overall costs of the customer. The value of the offer includes: the utility of the service, the value of personnel and service, the value of business reputation and the company's image rating, to the overall costs: financial and time costs, emotional losses, energy costs.

When creating a service environment of the company, one should pay attention to features and advantages over competitors, for this purpose, when researching the market, it is better to apply an extended model of service promotion that is relevant to specifics of this type of service.

The identified problems necessitate the development of the methodology for valuing customers' audit services. This in turn will allow audit companies to identify consumer expectations and effectively apply market-based tools (for example, marketing, logistics, management, innovation, etc.) in order to increase the loyalty of loyal customers and attract new ones.

\section{Literature Review}

Topical issues related to the quality of customer servicing in the service sector to increase the customer value perception and customer loyalty were considered in works of scientists from different countries.

Different approaches to determine the value of services are used by such authors as F. Kotler (2006), M. Belyavtsev (2003), A. Marshall (1993), I.I. Mazur and V.D. Shapiro (2008), A. Razumovskaya and F. Kotler (2006) understand the value of the service as : "the aggregate of benefits that a buyer wants to receive when purchasing a product or service". M. Belyavtsev (2003) gives a similar definition of the value of the service, while the author defines the customer value as "the appraisal of the buyer's ability to satisfy his needs, is defined as the difference between the total value of the product and its total costs". In their studies I.I. Mazur and V.D. Shapiro (2008) as M. Belyavtsev 
determine the value of the product as customer satisfaction. A. Marshall (1993) defined the value as an "equilibrium price, when marginal costs are comparable to marginal utility". According to this definition, the value of services should be understood as the integrity of the audit service quality and consumer characteristics aimed at meeting the demand of each customer.

A. Razumovskaya (2006) classifies the value of services as one of pricing methods that directly depend on the level of demand and on product features necessary for the buyer.

Cemal Zehir and Elif Narcıkara (2016) in their studies of electronic services assess the growth of successful results of commercial projects of companies in the Internet by improving the quality of not only the product but also the service quality. The authors conducted marketing research in the form of a survey of 645 customers and proved the direct relationship between the perceived value of services by customers and the quality of the producer's service.

Jerónimo García-Fernándeza and PabloGálvez-Ruíz (2017) consider the impact of the service quality and increasing customer loyalty in inexpensive fitness centers. Scientists assess the perceived service quality by consumers through effective management of organizations and reduce the time spent on the customer service, which helps reduce costs and create a budget variant of the business model.

In his study, Rajesh Rajaguru (2016) paid attention to the improvement of the airline service profitability through a value-based approach to determine the cost of services. The study looks at the consumer behavior, the relationship between low prices and the perceived value of airline services and the impact of the service quality and services on customer satisfaction. ChihHsing SamLiu and Tingko Lee (2016) are also analyzing the relationship between the quality of service delivery and the value approach to pricing airline services. Scientists tested 484 respondents, passengers of inexpensive airlines, to confirm their findings and prove the significant impact of the perceived value of services on customers' loyal attitude.

The quality and value of audit services is indirectly confirmed through the estimation of such indicators as: the level of income of the audit company, the number of agreements for audit; the share of revenues from general audit; the share in the total number of audit organizations.

\begin{tabular}{|c|c|c|c|c|c|c|c|c|}
\hline \multirow[t]{2}{*}{ Indicator } & \multirow{2}{*}{$\begin{array}{l}\text { Object of } \\
\text { Estimation }\end{array}$} & \multicolumn{7}{|l|}{ Years } \\
\hline & & 2010 & 2011 & 2012 & 2013 & 2014 & 2015 & 2016 \\
\hline 1 & 2 & 3 & 4 & 5 & 6 & 7 & 8 & 9 \\
\hline $\begin{array}{l}\text { Amount of services } \\
\text { provided - total, bln. } \\
\text { rubles }\end{array}$ & - & 49,1 & 50,8 & 51 & 51,7 & 53,6 & 56,1 & 57,1 \\
\hline $\begin{array}{l}\text { Growth in comparison } \\
\text { with the last year, } \%\end{array}$ & - & $-1,0$ & 3,5 & 0,5 & 1,4 & 3,7 & 4,7 & 1,8 \\
\hline \multirow[t]{3}{*}{$\begin{array}{l}\text { Revenues of audit } \\
\text { organizations - total, } \\
\text { mln. rubles }\end{array}$} & $\begin{array}{l}\text { Among the } 4 \\
\text { largest } \\
\text { companies } \\
\end{array}$ & 4262,9 & 4639,2 & 4752,5 & 4868,1 & $\begin{array}{l}5 \\
309,2\end{array}$ & $\begin{array}{l}5 \\
937,6\end{array}$ & 6124,1 \\
\hline & $\begin{array}{l}\text { Among typical } \\
\text { companies in } \\
\text { Moscow }\end{array}$ & 10,9 & 11,1 & 2.7 & 2,8 & 2,7 & 2,7 & 2,7 \\
\hline & $\begin{array}{l}\text { Among typical } \\
\text { regional } \\
\text { companies }\end{array}$ & 4,2 & 1,8 & 1,8 & 1,8 & 1,9 & 1,8 & 1,9 \\
\hline \multirow{3}{*}{$\begin{array}{l}\text { Share in the total number } \\
\text { of audit organizations, } \%\end{array}$} & Small & 87,5 & 87,3 & 88,4 & 89,4 & 91,1 & 91,6 & 90,8 \\
\hline & Medium & 11,2 & 11,4 & 10,3 & 9,4 & 7,7 & 7,2 & 7,9 \\
\hline & Big & 1,3 & 1,3 & 1,3 & 1,2 & 1,2 & 1,2 & 1,3 \\
\hline \multirow{3}{*}{$\begin{array}{l}\text { Share of income from } \\
\text { audit in total revenues } \\
\text { for the year, } \%\end{array}$} & Moscow & 47,1 & 44,9 & 51,2 & 53,6 & 51,5 & 48,5 & 47,6 \\
\hline & St. Petersburg & 40,2 & 37,6 & 38,1 & 36,8 & 39,5 & 46,6 & 47,4 \\
\hline & Other regions & 58,8 & 54,9 & 52,3 & 52,3 & 52,5 & 53,6 & 54,8 \\
\hline \multirow{3}{*}{$\begin{array}{l}\text { Share in the total number } \\
\text { of audit organizations, } \%\end{array}$} & Moscow & 35,6 & 36,1 & 35,7 & 35,4 & 35,4 & 35,4 & 34,4 \\
\hline & St. Petersburg & 9,0 & 9,0 & 9,2 & 9,1 & 9,2 & 9,1 & 9,2 \\
\hline & Other regions & 55,4 & 54,9 & 55,1 & 55,5 & 55,4 & 55,5 & 56,4 \\
\hline
\end{tabular}

Source: Information of the official website of the RF Ministry of Finance

Table 1. Dynamics of Changes in the Main Indicators of the Audit Market in Russia (The Main Indicators of the Audit Market in the Russian Federation in 2011-2016 (2018). 
The analysis of the market data for audit services in table 1 allows concluding that the largest amount of services in Russia is provided by the largest audit companies. These include multinational companies of the Big Four: PricewaterhouseCoopers (PwC), Deloitte (Deloitte), Ernst \& Young (EY), KPMG (KPMG). According to the research of M. Sindelar and L. Mullerova (2016), the Big Four occupies leading positions in the audit activity all over the world. According to the monitoring of the audit services market in the Czech Republic, the share of revenues of the Big Four companies in 2014 was 84\% of the total revenue of all audit companies.

The revenue growth rate in 2016 for the leading companies was $3 \%$ compared to previous periods, while the growth rates of other companies were low (domestic companies in Moscow - 0\%, regions - 5\%). For the period from 2010 to 2016, the revenue growth of the Big Four companies amounted to $43 \%$, while for domestic companies in Moscow for the same period, the income level decreased by $75 \%$. The situation also has a negative trend in regions of the country, which is confirmed by a $54 \%$ decline in the period under review. A significant difference in the amount of work raises the rating of the Big Four and makes their services a benchmark for quality in the market, the same effect of the impeccable business reputation is in the metropolitan audit market. Many large regional companies prefer Moscow companies, relying on their recognizable brands and large indicators of business activity. At the same time, according to the data of 2016, small companies occupy $90.8 \%$ of the total number of audit organizations. During the period under review, there is a negative trend in the decline in the share of medium-sized companies - direct domestic competitors of transnational companies, their share decreased by $30 \%$ as compared to 2010 . Some increase of this indicator in 2016 (10\%) did not affect their total income. Specialists note that this ratio of revenues and the number of companies on the market reflects the congestion of the audit market by small companies whose service quality is difficult to assess unequivocally, and accordingly, customers prefer recognizable brands of major players in the audit market. This fact underscores the importance of introducing new techniques into the work of small and medium-sized companies. Client-oriented, improving the quality of both the services provided, and the customer service allow small companies to increase competitive advantages, increase the value of their services and customer loyalty.

The purpose of this study is to develop the methodology for monitoring the customer value perception of audit services in small audit organizations.

\section{Materials and Methods}

The study used methods of economic and statistical analysis, expert estimations, questionnaires, mathematical methods and software products, empirical (description of facts, measurement and synthesis of research results, grouping, sampling) and experimental (development and approbation of models and methods) methods.

The customer pays attention to advertising campaigns of audit companies, brand recognition and its business reputation, including positive feedback from other clients about the work of the organization and its employees. Further, when concluding the agreement, the client estimates the cost of the service, the timing of the audit, the benevolence of attendants; when working with a supplier, the value of the service depends on the quality of the audit, the skills of its employees, and the suppliers' compliance with the customer's individual preferences. In case of a negative impression, special attention should be given to dissatisfied customers and their complaints, it makes possible not only to analyze disputable situations, but also to eliminate problems, to attract clients for further cooperation.

In his works, M. Botnaryuk (2010) examines the methodology for estimating the integral indicator of the value of services. Adapting this technique to the market of audit services, you can calculate the degree of the customer perception of audit services $\left(\mathrm{K}_{\mathrm{dcpas}}\right)$

$$
\mathrm{K}_{\text {dcpas }}=\mathrm{N}_{\text {one-use }} / \mathrm{N}_{\text {repeat, }}
$$

where $\mathrm{N}_{\text {one-use }}$ - the number of single-time cooperation agreements for the reporting period,

$\mathrm{N}_{\text {repeat }}{ }^{-}$the number of agreements with prolongation for the reporting period.

If the value of $\mathrm{K}_{\mathrm{dcpas}}$ is more than 1, then the company has a large influx of new customers in relation to permanent ones, which means developed marketing tools for promoting services and positive business reputation in the market. If the value of $\mathrm{K}_{\text {dpas }}$ is less than 1 , it indicates long-term relations with customers and the prolongation of agreements, therefore, consumers are satisfied with the quality of services provided and show loyalty to the supplier. However, in order to fully appreciate the level of customer satisfaction, it is necessary to consider a set of indicators and apply a systematic approach to the analysis of the value of audit services. As a consequence, a multi-stage methodology for analyzing 
the value perception of audit services was presented in this article.

Monitoring the customer value perception of audit services includes stages: calculating indicators influencing the customer, creating a matrix of the value estimation of audit services, filling in the customer's card who uses audit services, forming a unified customer accountancy database.

The matrix of the value estimation of audit services is formed on the basis of the analysis of the customer perception using a number of indicators. Matrix indicators enable audit companies to obtain complete information about customers in order to form an individual approach to each customer.

\section{Results}

At the first stage, to analyze the satisfaction of consumer personal wishes, it is proposed to calculate the indicator of the service compliance with the customer initial perception $\left(\mathrm{SCCP}_{\text {initial }}\right)$, if customers are taken into account, because transactions with them are more than $10 \%$ of their total volume. This indicator reflects the extent to which the service provider was able to satisfy the customer wishes at the time of signing the agreement:

$$
\mathrm{SCCP}_{\text {initial }}=\frac{\text { Nsatisfied wish }}{\text { Ndeclared wish }} \text {, }
$$

$\mathrm{N}_{\text {satisfied }}$ wish $^{-}$the number of the customer satisfied wishes,

$\mathrm{N}_{\text {decared wish }}$ - the number of the customer declared wishes.

The value of $\mathrm{SCCP}_{\text {initial }}$ is in the range from 0 to 1 . The higher the value of the indicator, the higher the satisfaction level of the customer wishes is.

At the end of the analyzed period, $\mathrm{SCCP}_{\text {final }}$ is introduced, reflecting the service compliance with the customer final perception, showing the level of customer satisfaction from cooperation with the agreementor. This indicator is based on scores and may have the following meanings:

1 point when concluding a re-agreement with the customer and full satisfaction of the customer wishes; 0,5 points, if the customer presents new requirements and conditions for cooperation when concluding a new agreement;

0 points if the customer refuses from further cooperation.

As applied to the audit services market, two specific indicators should be added to this methodology, which most fully reflect the relationship with the customer:

- Indicator of accounting for agreements concluded previously ( $\left.\mathrm{ACC}_{\text {previous }}\right)$;

- Indicator of accounting for agreements concluded in the reporting period ( $\left.\mathrm{ACC}_{\text {report }}\right)$;
- Indicator of accounting for the cost of service (ACS).

The $\mathrm{ACC}_{\text {previous }}$ indicator characterizes the past experience of working with the customer. The points are distributed according to the types of services provided in the previous period:

1 point - previously there was an agreement for audit; 0,5 points - previously there was an agreement for other services;

0 points - there was an agreement concluded for the first time.

According to K. Haksever (2002), as a rule, additional services are required to provide basic services. In the case of audit, these are other services that not only serve as an independent product, but can also be implemented together with the main audit product verification. The score of customers should be distributed according to the importance of the service, and we cannot eliminate the possibility of the mixed provision of services, which is not prohibited by law, i. e. summing points of services provided under one agreement.

The $\mathrm{ACC}_{\text {report }}$ indicator is calculated taking into account the services provided under the new agreement:

1 point if the audit agreement is concluded;

0.5 points, if the new agreement is concluded for other services.

The ACS indicator shows the actual payment for the service, taking into account discounts.

Points are distributed according to the payment made: 1 point - payment of the full cost of services according to the price-list;

0,5 points - discounts to customers up to $30 \%$;

0 points - discounts over $30 \%$.

In case if the customer violates the agreement terms to pay for audit services, 0 points are also credited.

There is also a criterion for estimating the buyer of services, which can affect the further cooperation cardinally - honesty and fair practices of the customer. At the beginning of the work, auditors are required to verify the customer legality to carry on business activity. Accordingly, the customer reputation can be characterized by the coefficient that has two meanings: 1 - when the customer is recognized as honest, 0 - if the customer's activity is unlawful. If the indicator has a value of 0 , further estimation of the customer does not make sense. The company falls into a separate "black" list of customers.

The next step is to build a matrix based on indicators described above.

With the help of the proposed matrix on valuing services, audit organizations can identify companies that are extortionists. If $\mathrm{CSCP}_{\text {initial }}$ is in the range of 
less than 0.4 and at the same time, $\mathrm{CSCP}_{\text {final }}$ is $0.5-1$ point, it means that buyers use the pressure approach to the seller, not wanting to abandon the services of this audit company in the future, especially if the company is already a constant customer, as evidenced by $\mathrm{ACC}_{\text {previous }}>0.5$.

The next stage is to develop a customer's card, which takes into account all his individual wishes, requirements, and data about the customer, according to which the seller loyalty is determined. The customer's card, adapted for the audit services market, is shown in Figure 4.

\section{Party A}

\begin{tabular}{|l|l|}
\hline \multicolumn{2}{|l|}{ Name of the customer (buyer) and his requisites: } \\
\hline \multicolumn{2}{|l|}{ Date of card formation: } \\
\hline Agreement number: \\
\hline No & Individual wishes \\
\hline 1 & \\
\hline$\ldots$ & \\
\hline n & \\
\hline
\end{tabular}

Party B

\begin{tabular}{|c|c|c|}
\hline No & $\begin{array}{l}\text { Customer information (criteria for } \\
\text { compulsory audit, estimation of the } \\
\text { customer loyalty to the seller to calculate } \\
\text { discounts and bonuses) }\end{array}$ & Values \\
\hline 1 & $\begin{array}{l}\text { Performance indicators in accordance with the } \\
\text { established criteria for mandatory audit }\end{array}$ & \\
\hline 2 & Duration of cooperation, years & \\
\hline 3 & $\begin{array}{l}\text { Type of services provided: } \\
\text { - audit - } 1 \text { point; } \\
\text { • other services - } 2 \text { points }\end{array}$ & \\
\hline 4 & $\begin{array}{l}\text { Cost of services according to the agreement: } \\
\text { - over } 2 \text { thousand dollars - } 1 \text { point; } \\
\text { - from } 1 \text { to } 2 \text { thousand dollars - } 2 \text { points; } \\
\text { - up to } 1 \text { thousand dollars - } 3 \text { points }\end{array}$ & \\
\hline 5 & $\begin{array}{l}\text { Timely payment for services: } \\
\text { - the terms of the agreement are complied } \\
\text { with, payment on time is } 1 \text { point; } \\
\text { - the account is paid with a delay of up to one } \\
\text { month - } 2 \text { points; } \\
\text { - the account is paid with a delay of more } \\
\text { than one month - } 3 \text { points }\end{array}$ & \\
\hline 6 & $\begin{array}{l}\text { Accurate compliance with all terms of the } \\
\text { agreement: yes (+), no (-), partial observance } \\
\text { of conditions }(+/-)\end{array}$ & \\
\hline 7 & Other criteria at the request of the organization & \\
\hline
\end{tabular}

Fig 4. The Customer's Card of Audit Services
The maintenance of such cards can significantly assist small audit companies in their work with clients. When they are filled out, the customer's necessary private needs for the specific service are identified, which increases the value of these services and positively affects competitive advantages of the audit organization. This helps to calculate discounts and bonuses, while avoiding extortion from customers.

The collection of cards data of all customers is a file of clients with complete information about each of them. At the same time, the use of modern information technologies makes it possible to group customers' cards according to a wide variety of characteristics in accordance with the requests of management of audit companies.

At the third stage, it is proposed to identify the most frequently encountered requirements. To do this, all wishes are entered in the summary table, then, when analyzing them, the business analyst of the audit company identifies recurring requirements and determines their relative importance in the total volume of wishes. For example, if the same desire is repeated for 8 customers out of 10 , then the specific weight is $80 \%$. At the same time, it is necessary to group the requirements by the frequency of their presentation and, first of all, pay attention to those requirements, whose specific gravity is greater. Next, the following analytical table is formed, where the wishes are divided into groups (production and nonproduction factors), then the points are scored that determine the frequency of wishes. As part of the analysis of companies in the audit market, it is proposed to fix the requirements in a single table, which will shorten the time spent on data systematization and processing. This form is presented in Table 2. It is suggested to use spreadsheets such as Microsoft Office Excel. Companies - customers are recorded horizontally, dates of information gathering are fixed for the prompt search of questionnaires and agreements of customers on a card file. Opposite the graph with the desire we put a unit; if this wish is revealed for the first time, it is entered vertically into the table and also marked with a unit in the company graph. This system allows you to not re-define each time the specific weight of the desire, and use the calculated capabilities of the software product.

\begin{tabular}{|l|l|l|l|l|l|l|l|l|l|}
\hline No & $\begin{array}{l}\text { Name of the } \\
\text { customer's individual } \\
\text { wishes }\end{array}$ & Company & $\begin{array}{l}\text { Customer } \\
\text { A }\end{array}$ & $\begin{array}{l}\text { Customer } \\
\text { B }\end{array}$ & $\begin{array}{l}\text { Customer } \\
\text { C }\end{array}$ & N & $\begin{array}{l}\text { Total } \\
\text { wishes, } \\
\text { units }\end{array}$ & $\begin{array}{l}\text { Total } \\
\text { customers, } \\
\text { units }\end{array}$ & $\begin{array}{l}\text { Specific } \\
\text { weight } \\
\text { of } \\
\text { wishes, } \\
\%\end{array}$ \\
\hline
\end{tabular}


Helix Vol. 8(5): 3593- 3599

\begin{tabular}{|c|c|c|c|c|c|c|c|c|c|}
\hline & Production & Date & 00.00 .00 & 00.00 .00 & 00.00 .00 & $\mathbf{N}$ & & & \\
\hline 1 & $\begin{array}{l}\text { Work experience with } \\
\text { similar organizations }\end{array}$ & & 1 & & 1 & & 2 & & 67 \\
\hline 2 & $\begin{array}{l}\text { Attraction of } \\
\text { specialized third-party } \\
\text { specialists }\end{array}$ & & & 1 & 1 & & 2 & & 67 \\
\hline \multirow[t]{2}{*}{3} & $\begin{array}{l}\text { Correction of terms of } \\
\text { services }\end{array}$ & & 1 & & & & 1 & & 33 \\
\hline & Non-production & & & & & & & & \\
\hline 1 & $\begin{array}{l}\text { Limitation of } \\
\text { communication with } \\
\text { some employees for } \\
\text { information collection }\end{array}$ & & & & 1 & & 1 & & 33 \\
\hline 2 & $\begin{array}{l}\text { Change in the advance } \\
\text { payment }\end{array}$ & & 1 & 1 & 1 & & 3 & & 100 \\
\hline \multirow[t]{2}{*}{3} & $\ldots$ & & $\ldots$ & $\ldots$ & $\ldots$ & $\ldots$ & $\ldots$ & 3 & $\ldots$ \\
\hline & Total & & 3 & 2 & 4 & & 9 & & \\
\hline
\end{tabular}

Table 2. The Uniform Form of the Customer's Individual Wishes

After analyzing the data in Table 2, wishes with the largest shares in their total number are identified, therefore, in order to increase the value of services, it is necessary to take into account, first of all, the most frequent wishes. This table allows identifying the hidden potential to increase the competitive advantage in the audit market, increases the effectiveness of management, positively affects the customer perception, and improves the company's business activity.

A competent assessment of requirements and working conditions for auditors, detailed drafting of the agreement is the key to maintain the cost of the audit at a reasonable level, which helps to remain competitive in the services market. Another important factor is the minimization of conflicts and disagreements with customers, which keeps the level of business reputation in the market and illustrates the professionalism of the company.

\section{Discussion}

The expected value of audit services consists of the need to purchase a service and a set of properties that increase its importance for consumers. The satisfaction of customers with audit services depends on the quality of the service provided, since independent confirmation of the organization's reporting data provides it with the confidence of business partners and regulators, assures confidence in the correctness of economic indicators and, therefore, reduces the risk of penalties from state bodies, and also excludes the concealment of important information for owners and investors. Thus, the customer will prefer the audit company with the impeccable business reputation more than with the reduced cost of services, since the low price is an indicator of the possible economy of the auditor on quality characteristics of the service.

The consumer cost of services consists of specific expectations of the client, such as:

- Low price for the service;

- Satisfaction of the customer's needs and desires regarding the chosen service;

- A high quality of providing services and servicing.

According to the research of I.I. Mazur and V.D. Shapiro (2008), the customer value of the service can be viewed as the expected cost of this service, which complements the definition of M. Belyavtsev (2003). Such customer value, expressed by customer satisfaction can be calculated by the formula:

Customer satisfaction $(\mathrm{C})=$ Service quality $=$ Value (V) / Service cost (Sc).

The expected value for customers consists of the need to purchase a product or service and a set of its features and qualities that increase the importance for the customer. However, according to M. Porter, to form a more specific value of services to their original cost, it is also necessary to include unplanned, additional costs for the service: operating costs, transportation costs, difference in the resale of the service, and the ability to generate revenues.

Audit refers to highly professional services, respectively, the main criteria for assessing the quality are technical performance characteristics expressed in compliance with the requirements of approved auditing standards. The service quality can be assessed only after the provision of these services.

The service quality is confirmed through the estimation of such parameters of the company's activity as compliance with the Federal Law "On 
Auditing", federal and internal audit standards, requirements of self-regulatory audit organizations. In order to increase the demand for services, the study of existing approaches to the value of audit services and their adaptation to features of a specific company, the analysis of the influence of the value approach on the pricing of the audit company and the quality of its audit services as a whole become relevant.

\section{Conclusion}

Within the framework of the study, the authors established regularities of decision-making by customers when purchasing services of audit organizations, which helps to identify not only loyal customers, but also to identify negative responses to services provided. Timely individual work with customer's complaints allows increasing the value of services and involving them in further cooperation. The paper reveals the role of quality in achieving the effectiveness of audit services and increasing their value. This is due to value factors of demand generation presented in the work, according to which the customer value of audit services depends on the quality of service delivery, namely, on the experience and level of employees' skills in the audit company.

The presented stages of monitoring the customer value perception of audit services allow producers to determine the level of customer satisfaction; to develop a customer-focused strategy for interviewing customers of audit services in order to identify complaints and individual wishes and to find ways and means of influencing customers' decision-making on cooperation with the audit organization to enhance the perceived value and quality of audit services.

\section{References}

1. Belyavtsev, M., Ivanenko, L.: Marketing, Donetsk: (b. I.), 340 (2003).

2. Botnaryuk, M.: Forming the value of maritime transport hub services: new benchmarks. Management in Russia and abroad. 6, 43-51 (2010).

3. Chih-Hsing, S. L., Tingko, L.: Service quality and price perception of service: Influence on word-ofmouth and revisit intention. Journal of Air Transport Management. 52, 4254 (2016), http://www.sciencedirect.com/science /article/pii/S0969699715301034.

4. García-Fernández, J., Gálvez-Ruíz, P. FernándezGavira, J., Vélez-Colónc, L., Pitts, B., BernalGarcía, A.: The effects of service convenience and perceived quality on perceived value, satisfaction and loyalty in low-cost fitness centers. Procedia Social and Behavioral Sciences. 20,325-
426. (2017), http://www.sciencedirect.com/scien ce/article/pii/S1441352317300621.

5. Haksever, K. Management and organization in the service sector: theory and practice (Per. S angl., N. Levkina, O. Sergeyeva, 2-ye mezhdunarod. Izd.). Sankt-Peterburg [i dr.]: Piter, 751 (2002).

6. Kotler F.: Basics of marketing (translation from English, new edition). Moskva [i dr.]: Vil'yams, 646 (2006).

7. Lanskov, D.P.: Menedenaliz quality of services as a prerequisite for improving the competitiveness of the organization. Economic sciences. Ekonomicheskiye nauki. 1, 138-140, (2011).

8. Marshall, A. Principe of Economics (perevod s angliyskogo: Kn. 3). Moskva: Izd. gruppa «Progress», 351 (1993).

9. Mazur, I.I., Shapiro V.D.: Quality management: qualification and competitiveness of quality, modern quality management (5-ye izd.). Moskva: Omega-L, 399 (2008).

10. Porter, M.: Competitive strategy. Technique of analysis of industries and competitors (translated from English), Moscow: Alpina Biznes Buks, 454 (2017).

11. Rajaguru, R.: Role of value for money and service quality on behavioural intention: A study of full service and low cost airlines. Journal of Air Transport Management. 53, 114-122, (2016), http://www.sciencedirect.com/science/article/pii/ S096969971530096X.

12. Razumovskaya, A., Yachenko, V.: Marketing services: a benchmark Russian marketerpractitioner.Moskva: Vershina, 112 (2006).

13. Sindelar, M., Mullerova, L.: Market Concentration of Audit Services in the Czech Republic: Empirical Evidence (Focusing on Auditors of Public Interest Entities). Politicka Ekonomie. 6(64), 730-746 (2016),

https://apps.webofknowledge.com/full_record.do ?product $=$ WOS \&search_mode $=$ GeneralSearch \& qid=3\&SID=S1PNELqY9kaYWzhv2Jj\&page $=1$ $\&$ doc $=2 \&$ cacheurlFromRightClick=no .

14. The main indicators of the market of audit services in the Russian Federation in 2011-2016. Information of the official website of the Ministry of Finance of the Russian Federation. (2018, March 30), https://www.minfin.ru/ru/perfomance/audit/audit _stat/MainIndex/.

15.Zehira, C., Narcıkara E.: E-Service Quality and ERecovery Service Quality: Effects on Value Perceptions and Loyalty Intentions. Procedia Social and Behavioral Sciences. 229, 427443. (2016), http://www.sciencedirect.com/science/article/pii/ S1877042816310886 . 